Çukurova Üniversitesi Mühendislik Fakültesi Dergisi, 36(4), ss. 997-1004, Aralık 2021

Cukurova University Journal of the Faculty of Engineering, 36(4), pp. 997-1004, December 2021

\title{
An Investigation on Decomposition of Signals and Noise Removal with a Half Band Nyquist Filter
}

\author{
İclal ÇETIN TAŞ*1 ${ }^{* 1}$ ORCID 0000-0002-1101-9773 \\ Sami ARICA ${ }^{2}$ ORCID 0000-0002-3820-029X
}

${ }^{1}$ Ostim Technical University, Faculty of Engineering, Department of Software Engineering, Ankara

${ }^{2}$ Çukurova University, Faculty of Engineering, Department of ElectricalElectronics Engineering, Adana

Geliş tarihi: 09.07.2021

Kabul tarihi: 10.12 .2021

Atıf şekli/ How to cite: TAŞ, I.Ç., ARICA, S., (2021). An Investigation on Decomposition of Signals and Noise Removal with a Half Band Nyquist Filter. Çukurova Üniversitesi, Mühendislik Fakültesi Dergisi, 36(4), 997-1004.

\begin{abstract}
Medical signal processing is often used for analyzing and detecting diseases from bio-signals. Segmentation, filtering, and noise removal are application examples in this area. The segmentation or decomposition of signals is investigated in this study. Each branch of two band quadrature-mirror orthogonal filter bank structure (analysis and synthesis parts are cascaded) is a half band Nyquist filter when down-up samplers are removed. To perform partitioning, one branch of the filter bank was adapted to a component of input signal to suppress the other element and filter out the target part of the signal. This was done by obtaining the filter-tap weights, which minimize $L_{1}$ - norm of error at the output. This goal was achieved by employing the exhaustive search method. The filter performance was tested for three scenarios: filtering with and without down-up samplers and wavelet de-noising using one-level decomposition. The comparison was done with Daubechies and Symlet filters. The approach was run and tested for separating synthetically generated evoked potential from noise, and the results show that the designed filter achieves lower total absolute error than the classical wavelet filters.
\end{abstract}

Keywords: Exhaustive search, Filter bank, Noise removal, Nyquist filter, Signal decomposition

\section{Yarım Bant Nyquist Filtre ile Sinyallerin Ayrıştırılması ve Gürültünün Giderilmesi Üzerine Bir Araştırma}

Özet

Medikal sinyal işleme sıklıkla biyo-sinyalleri analiz etmek ve onlardan hastalıkların tespitinde kullanılır. Bölütleme, filltreleme ve gürültü giderme bu alandaki uygulama örnekleridir. $\mathrm{Bu}$ çalışmada sinyallerin bölütlenmesi veya ayrıştırılması incelenmiştir. İki bantlı çeyrek ayna ortogonal filtre çatısına ait yapının

*Sorumlu (Corresponding author) yazar: İclal ÇETIN TAŞ, iclal.cetintas@ostimteknik.edu.tr 
her bir dalı (analiz ve sentez bölümleri seri bağlıdır), aşağı ve yukarı örnekleyiciler çıkarıldığında yarım bant Nyquist filtresidir. Ayrıştırma gerçekleştirmek maksadıyla, süzgeç çatısının bir dalı, işaretin bir bileşenini bastırmak ve diğer bileşenini elde etmek için bir hedef işaretine uyarlanmıştır. Bu işlem çıkışta $L_{1}$ - hata normunu en aza indiren filtre ağırlıkları elde edilerek yapılmıştır. Bu hedefe, kapsamlı arama yöntemi kullanılarak ulaşılmıştır. Filtre performansı üç senaryo için test edilmiştir: aşağı ve yukarı örnekleyiciler ile bunlar olmadan filtreleme ve tek seviyeli ayrıştırma kullanarak dalgacık gürültü giderme. Önerilen yöntemle elde edilen filtre, Daubechies ve Symlet filtreleri ile karşılaştırılmış̧ır. Yaklaşım yapay olarak oluşturulan uyarılmış potansiyelini gürültüden ayırmak için çalıştırılmış ve test edilmiştir. Elde edilen sonuçlar, tasarlanan filtrenin klasik dalgacık filtrelerinden daha düşük toplam mutlak hata sağladığını göstermiştir.

Anahtar Kelimeler: Kapsamlı arama, Süzgeç çatısı, Gürültü giderme, Nyquist süzgeci, sinyal ayrıştırma

\section{INTRODUCTION}

Biomedical signals are commonly used for understanding functionality of the body and diagnosis of diseases. These signals may contain specific patterns such as QRS wave [1] in an electrocardiogram (ECG) and evoked potential in an electroencephalogram (EEG), which are vital for analysis and diagnosis [2,3]. However, there are different types of noises in biomedical signals, which mask patterns, and they may cause mistakes in diagnosing and analysis steps. For that reason, researchers need to remove undesired parts of the signal. So, filters are required to reduce noise. The filter banks have received attention and frequently employed in noise reduction.

A filter bank is a group of parallel low-pass, bandpass and high-pass filters that separate the input signal into multiple components, each one carrying a single frequency sub band of the original signal [4,5]. In the present work, we are going to benefit from a two-channel filter bank [6]. The process of decomposition performed by the filter bank is called analysis. The reconstruction process is named synthesis, meaning reconstitution of a complete signal resulting from the filtering process. The wavelet transform-based noise cancellation methods are application of two band filter banks and more successful than linear filtering techniques [7,8]. In this study, we considered a signal as a sum of two components: base and background or noise. An orthogonal two band filter-bank system embodying cascaded analysis and synthesis parts was employed, and one branch was matched to the base signal so that this connection filters out the base and other branch separates the background signal from the composite signal. So as to obtain the filter tapweights, which minimize $L_{1}$-norm of error, the best solution among the other results satisfying perfectly reconstruction conditions of a quadrature-mirror filter-bank (QMF) was chosen, namely brute-force approach was used to find a solution. The proposed technique has been demonstrated by using a typical synthetic evoked potential signal.

This study consists of seven parts. First part is introduction which gives literature information for comparison our study. In second and third ones include the proposed method explanation and method's mathematical model with its details. The fourth and fifth ones consist experimental procedure and result investigation. The last part of before the reference is conclusion.

\section{MATERIAL AND METHOD}

Because the Nyquist filter is based on the filters of a two-band filter bank system, the two-band filter bank structure has been revisited.

\subsection{Two Band Filter Bank}

A two-band filter-bank system consisting of the analysis and synthesis components is shown in Figure 1. 


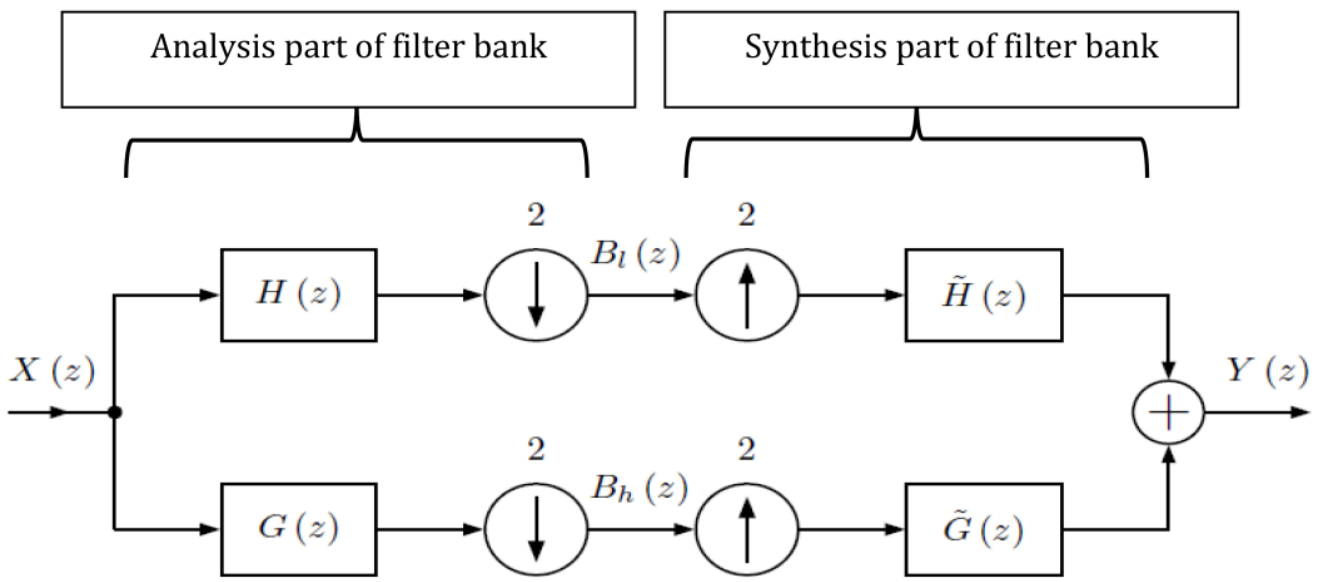

Figure 1. A two band filter bank with analysis and synthesis sections

The z-domain input-output relationship is as follows.

$$
\mathrm{Y}(\mathrm{z})=\frac{1}{2} \mathrm{~T}(\mathrm{z}) \mathrm{X}(\mathrm{z})+\frac{1}{2} \mathrm{~A}(\mathrm{z}) \mathrm{X}(-\mathrm{z})
$$

In this equation

$$
\begin{aligned}
& T(z)=H(z) \tilde{H}(z)+G(z) \tilde{G}(z) \\
& A(z)=H(-z) \tilde{H}(z)+G(-z) \tilde{G}(z)
\end{aligned}
$$

$T(z)$ is named as transfer function, and $A(z)$,will be called aliasing contribution (part), excluding the factor $1 / 2$ in Equation (1). For orthogonal system consisting of finite impulse response filters:

$$
\begin{aligned}
& \mathrm{H}(\mathrm{z})=\mathrm{z}^{-\mathrm{N}} \mathrm{H}\left(\mathrm{z}^{-1}\right) \\
& \tilde{G}(z)=z^{-N} G\left(z^{-1}\right)
\end{aligned}
$$

where $\mathrm{N}$ is the filter order. If the function and the aliasing part are arranged according to this selection,

$$
\begin{aligned}
& T(z)=z^{-N}\left[H(z) H\left(z^{-1}\right)+G(z) G\left(z^{-1}\right)\right] \\
& A(z)=z^{-N}\left[H(-z) H\left(z^{-1}\right)+G(-z) G\left(z^{-1}\right)\right]
\end{aligned}
$$

In addition, if $G(z)$ is chosen as the quadrature mirror of $H(z)$ as described in the following, the aliasing components disappears when $\mathrm{N}$ is odd, that is $A(z)=0$.

$$
\mathrm{G}(\mathrm{z})=\mathrm{z}^{\mathrm{N}} \mathrm{H}\left(-\mathrm{z}^{-1}\right)
$$

Hence the transfer function becomes:

$$
\mathrm{T}(\mathrm{z})=\mathrm{z}^{-\mathrm{N}} \mathrm{P}(\mathrm{z})
$$

$$
\mathrm{P}(\mathrm{z})=\mathrm{H}(\mathrm{z}) \mathrm{H}\left(\mathrm{z}^{-1}\right)+\mathrm{H}(-\mathrm{z}) \mathrm{H}\left(-\mathrm{z}^{-1}\right)
$$

If $P(z)=2$, a perfect reconstruction is obtained, and the output turns into shifted version of the input:

$$
\mathrm{Y}(\mathrm{z})=\mathrm{z}^{-\mathrm{N}} \mathrm{X}(\mathrm{z})
$$

Consequently, the perfect reconstruction condition in $z$ and time domains are as follows.

$\mathrm{H}(\mathrm{z}) \mathrm{H}\left(\mathrm{z}^{-1}\right)+\mathrm{H}(-\mathrm{z}) \mathrm{H}\left(\mathrm{z}^{-1}\right)=2$

$\sum_{\mathrm{n}=0}^{\mathrm{N}-2 \mathrm{k}} \mathrm{h}(\mathrm{n}) \mathrm{h}(\mathrm{n}-2 \mathrm{k})=\delta(\mathrm{n}) \quad \mathrm{k}=1,2, \frac{\mathrm{N}+1}{2}$

More details about two-band quadrature filter bank can be found in [2,3]. Set $B_{h}(z)=0$ in Figure 1; 
this equivalent to setting $G(z)$ to zero in Equation (6), Equation (7). This yield

$$
Y(z)=\frac{1}{2} z^{-N} H(z) H\left(z^{-1}\right) X(z)
$$

where,

$$
\begin{aligned}
& P_{1}(z)=H(z) H\left(z^{-1}\right)+H(-z) H\left(-z^{-1}\right) \\
& A_{1}(z)=z^{-N} H(-z) H\left(-z^{-1}\right)
\end{aligned}
$$

The term $A_{1}(z) X(-z) / 2$ in the right side of Equation (14) is a residual aliasing.

\subsection{Two Band Filter Bank Without Down and Up Samplers}

When down and up-samplers operations are removed from analysis and synthesis procedure (Figure 1) the aliasing term in Equation (1) disappears and the input-output relation in $\mathrm{Z}$ domain becomes

$$
\mathrm{Y}(\mathrm{z})=\mathrm{T}(\mathrm{z}) \mathrm{X}(\mathrm{z})
$$

By substituting Equation (9) in Equation (17), we have

$$
Y(z)=z^{-N} P(z) X(z)
$$

The perfectly reconstruction condition given in Equation (13) remains valid in this case too. However, the output becomes double of the input in contradistinction of the previous situation:

$$
Y(z)=2 z^{-N} X(z)
$$

As it has been done in the previous sub-section setting $B_{h}(z)$ to 0 (equivalently $\mathrm{G}(z)=0$ ) yields

$$
\mathrm{B}_{\mathrm{h}}(\mathrm{z})=\mathrm{z}^{-\mathrm{N}} \mathrm{P}_{1}(\mathrm{z}) \mathrm{X}(\mathrm{z})
$$

It should be emphasized that there is no residual aliasing energy since down and up-samplers were removed. $P_{1}(z)$ is a symmetric polynomial of $\mathrm{z}$ and has only even powers of $z$. It should be noted that $P_{1}(z)$ fulfils properties of a half band Nyquist filter [9].

\section{SIGNAL/PATTERN DECOMPOSITION}

Many signals, including medical ones can be modelled as the sum of a pattern and background (or clear signal plus noise) signals:

$$
x(n)=p(n)+b(n)
$$

Here $p(n)$ is the pattern; $b(n)$ is the background signal. Suppose this signal is applied to the filter bank shown in Figure 1, and the pattern-energy mostly resides in $B_{1}(z)$ and the backgroundenergy in $B_{h}(z)$. When $B_{h}(z)=0, Y(z)$ becomes a shifted version of the pattern if residual aliasing is ignored. In this case, if $H(z)$ is designed by minimizing $L_{1}$-norm of error between the filter bank output and the pattern signal, a two-band filter bank satisfying segmentation of the signal is obtained. This issue is a constraint optimization problem. It is described in the following.

If $B_{h}(z)=0$, (Equation 14) output signal in timedomain is

$\mathrm{y}(\mathrm{n})=\frac{1}{2} \mathrm{x}(\mathrm{n}+\mathrm{N}) * \mathrm{~h}(\mathrm{n}) * \mathrm{~h}(-\mathrm{n})$

$+\frac{1}{2} x(n+N) *(-1)^{n} h(n) * h(-n)$

and when there is no up-down sampling (Equation 20) it turns into

$\mathrm{y}(\mathrm{n})=\mathrm{x}(\mathrm{n}+\mathrm{N}) * \mathrm{~h}(\mathrm{n}) * \mathrm{~h}(-\mathrm{n})$

where is the convolution operator. To suppress noise signal and obtain a filter bank matched to the pattern we employ following optimization algorithm. Here Equation (25) is perfectly reconstruction condition and Equation (26) is for 
completely suppressing frequency at $\omega=$ $\pi \mathrm{rad} / \mathrm{s}$. This approach allows designing filter $H(z)$ by attaining minimum $L_{1}$--norm of error between the target and filtered signals $L_{1}$-norm is preferred instead of $L_{2}$-norm for error calculation and is used as objective function because it produces a sparse solution and is robust against outliers [10]. However, there can be a highfrequency component (fluctuations) in the decomposed signal due to the aliasing component which is not overthrown when standard form of the filter bank is employed. Because Equation (24) is not smooth, the derivative of it does not exist at about its minimum, and therefore, a gradient-free method should be adopted. $y(n)$ is computed by Equation (22), Equation (23).

$$
\min _{\mathrm{h}(\mathrm{n})} \sum_{\mathrm{n}}|\mathrm{p}(\mathrm{n})-\mathrm{y}(\mathrm{n})|
$$

Subject to

$$
\begin{aligned}
& \sum_{n=0}^{N-2 k} h(n) h(n-2 k)=\delta(k) \\
& k=0,1, \ldots,(N+1) / 2 \\
& \sum_{n=0}^{N-2 k}(-1)^{n} h(n)=0
\end{aligned}
$$

\subsection{Finding an Optimal Solution with Exhaustive Search}

To obtain as much as the best solution, the exhaustive search approach was employed. The exhaustive search (brute force method) is straightforward, which try to calculate all possible solutions and decides afterwards which one is the best. This method is feasible generally for smallscale problems, since the number of possibilities of the system increases exponentially with the number of dimensions. It has wide applicability and is known for its simplicity. First, a set of (all possible) solutions satisfying the perfect reconstruction conditions in Equation (25) and the requirement in equation Equation (26) were generated, and next objective function in Equation (24) was computed for all solutions in this set. The one satisfying minimum of Equation (24) was chosen.

\section{EXPERIMENTS}

The technique suggested has been demonstrated on an artificial evoked potential signal. Evoked potentials (EPs) are types of bio-electrical signals that are generated by the central nervous system when human senses are excited by an external stimulus. In order to demonstrate the proposed algorithm a typical evoked potential signal was generated synthetically. The time-interval and sampling-rate were chosen to be 0.2 and $320 \mathrm{~Hz}$ respectively. The extreme value of the signal was normalized to be -1 since it was negative. This clean EP signal is sketched in Figure 2. The evoked potentials are usually contaminated by heavy noise or responses to other activities of the human body and are nearly impossible to detect from a single trial. To resemble this reality a normally distributed random noise with zero mean and 0.01 variance was added to the pure EP signal. The noisy EP is presented in Figure 2. The order of the FIR filter was set to be seven. The filter weights were obtained by using the exhaustive search algorithm given. Because of non-linearity and the number of equations is less than the number of variables, there is more than one solution of the systems of equations given in Equation (25), Equation (26). Firstly, hundred possible solutions of these equations were computed numerically by randomly changing initial values 100 times. Very likely, many solutions coincided. Next, $L_{1}$-norm of error expressed in Equation (24) was computed for each solution. The filter coefficients which achieve the lowest absolute error was chosen as the optimal 
solution. Following filter specification, a new by employing the structures given in Figure 3 and noisy evoked potential was generated and filtered 4 to observe the effectiveness.

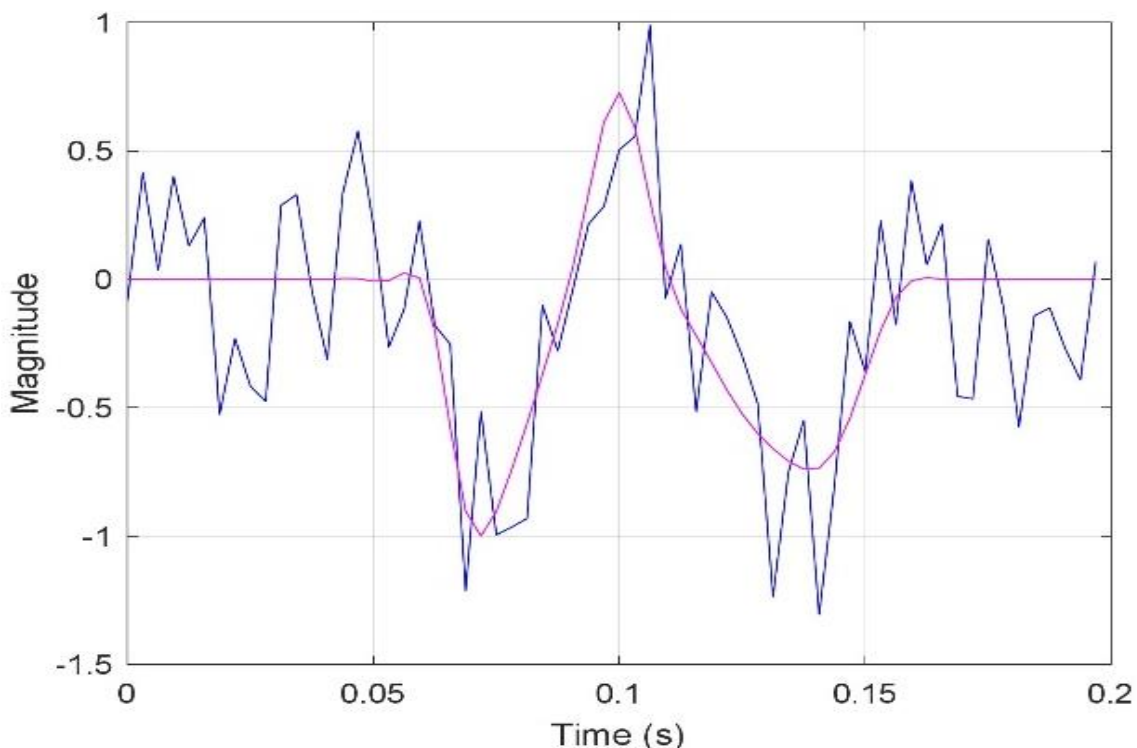

Figure 2. Noisy and clean synthetic evoked potential

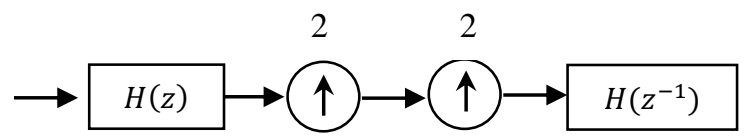

Figure 3. Experiment 1

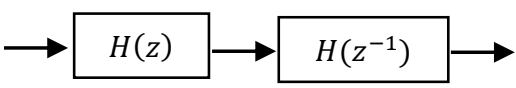

Figure 4. Experiment 2

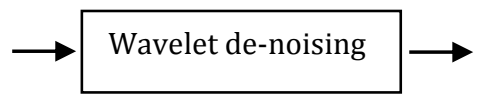

Figure 5. Experiment 3

The wavelet de-noising was also applied. The wavelet tree was a single two-band filter bank of optimum filter weights. The soft thresholding technique and universal threshold [11] were utilized for removing noise from the signal. For comparing performance of the best filter, Symlet, and Daubechies wavelet filters of length eight were also handled. The outcomes, in terms of $L_{1-}$ norm of error, were finally reported.

\section{RESULTS}

After the best filter-coefficients were obtained a fresh noisy evoked potential was produced, and it was filtered by utilizing the structures in Figure 3 . to evaluate performance of the approach. The arrangements in Figure 3, Figure 4 and Figure 5 are referred to as E1 (Experiment 1), E2 (Experiment 2) and E3 (Experiment 3) 
respectively. And the optimal filters obtained for E1, E2, and E3 are denoted by F1 (Matched Filter 1), F2 (Matched Filter 2), and F3 (Matched Filter 3) accordingly.

Table 1. Best filter coefficients $(\mathrm{C} 1, \mathrm{C} 2, \ldots \mathrm{C} 8)$ for the three experiments

\begin{tabular}{|c|c|c|c|c|c|c|c|c|}
\hline & C1 & C2 & C3 & C4 & C5 & C6 & C7 & C8 \\
\hline F1 & 0.23 & 0.18 & 0.42 & 0.41 & -0.26 & 0.49 & 0.30 & -0.38 \\
\hline F2 & 0.48 & 0.32 & 0.41 & -0.36 & -0.04 & 0.52 & -0.15 & 0.22 \\
\hline F3 & -0.19 & 0.09 & -0.03 & 0.30 & 0.68 & -0.21 & 0.24 & 0.52 \\
\hline
\end{tabular}

Table 2. Performance comparison

\begin{tabular}{|c|c|c|c|c|c|}
\hline & F1 & F2 & F3 & SYM & DB \\
\hline E1 & 0.183 & 0.259 & 0.187 & 0.184 & 0.194 \\
\hline E2 & 0.367 & 0.299 & 0.362 & 0.458 & 0.458 \\
\hline E3 & 0.194 & 0.255 & 0.192 & 0.182 & 0.195 \\
\hline
\end{tabular}

The wavelet de-noising method serves as a reference for the goodness of proposed approach. For the sake of clarity in tables, Symlet filter is abbreviated as SYM and Daubechies filter as DB. The weights of filters which achieve minimum absolute error for each experiment are given in Table 1. Notice that the best filter coefficients change for each arrangement in Figure 3. The efficiencies of custom, Symlet and Daubechies filters, in terms of $L_{1}$-norm of error, are provided in Table 2. Figure 6 displays the magnitude and phase spectra of the best filter of the experiment in Figure 3. And Figure 7 illustrates outputs of the structure in Figure 3.

The similarity between the matched (optimal) filter and Symlet and Daubechies filters was measured by employing correlation coefficient and cosine similarity. These quantities are given in Table 3 . The upper number is the correlation coefficient, and the bottom value is the cosine similarity in a cell of this Table. It is obvious that the best solutions obtained for three arrangements are quite different than Symlet and Daubechies filters.
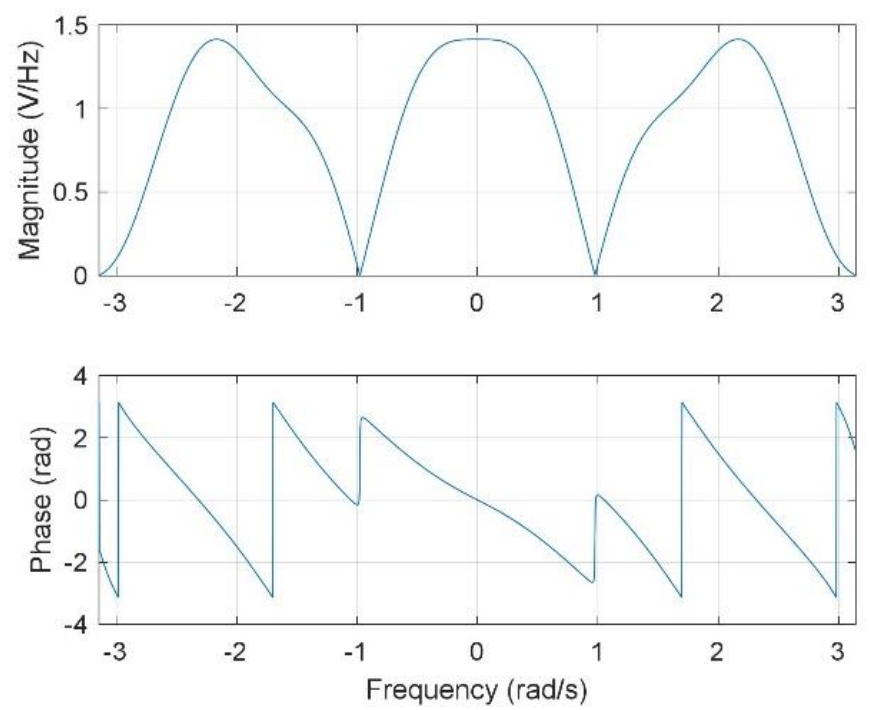

Figure 6. Magnitude and phase spectra of the matched filter of experiment 1.

\section{CONCLUSIONS}

Filter banks and wavelet-based applications can be successfully used to solve noise suppression, and decomposition problems in signal processing area. In this study, a two-band quadrature-mirror orthogonal filter bank structure, consisting of analyses and synthesis sections, was used to emphasize and extract one components of input signal; one branch of the filter bank was adopted to filter out a target signal. This was done by minimizing $L_{1}$-norm of error by utilizing bruteforce search technique at the output of the filter bank system. 
Table 3. Performance comparison

\begin{tabular}{|l|c|c|c|}
\hline \multirow{2}{*}{ SYM } & F1 & F2 & F3 \\
\cline { 2 - 4 } & 0.1636 & -0.5861 & 0.3135 \\
\hline \multirow{2}{*}{ DB } & 0.3765 & -0.1896 & 0.4851 \\
\cline { 2 - 4 } & 0.1828 & 0.1503 & -0.2180 \\
\hline
\end{tabular}
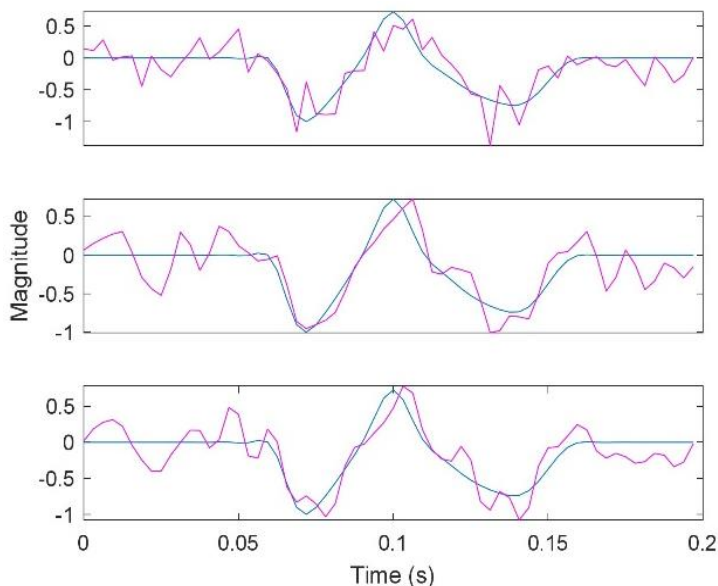

Figure 7. Filter outputs. The above, mid and bottom figures are outcomes of the matched, Symlet and Daubechies

The approach was run and tested for a typical, synthetically generated evoked potential signal arising in an electroencephalogram. The performances of designed filters were compared, in terms of $L_{1}$-norm of error, with two common wavelet filters: Symlet and Daubechies. The results show that the designed filters achieve lower inaccuracy than the common wavelet filters. Consequently, a filter specified by adopting the proposed approach can be used for signal decomposition or noise suppression as an alternative to common wavelet filters.

\section{REFERENCES}

1. Gurkan, H, Hanilci, A., 2020. ECG Based Biometric Identification Method Using QRS Images and Convolution Neural Network. Pamukkale University Journal of Engineering Sciences, 26(2), 318-327.

2. Rangaraj, MR., 2015. Biomedical Signal Analysis. IEEE Press Series on Biomedical Engineering, $2^{\text {nd }}$ edition. Wiley-IEEE Press.
3. Ergun, E., Aydemir, O., 2018. Improving Classification Accuracy of Motor Imagery EEG Signals Via Effective Epochs. Pamukkale University Journal of Engineering Sciences, 24(5), 817-823.

4. Gilbert, S, Truong N., 1996. Wavelets and Filter Banks, $2^{\text {nd }}$ edition. Wellesley-Cambridge Press.

5. Vaidyanathan, PP., 1990. Multirate Digital Filters, Filter Banks, Polyphase Networks, and Applications: A Tutorial. Proceedings of the IEEE 1990; 78(1), 56-93. doi: $10.1109 / 5.52200$.

6. Kamislioglu B, Karaboga N., 2019. Investigation of the Performance of the Kaiser Hamming Window in Design of QMF Bank. Pamukkale University Journal of Engineering Sciences, 25(2), 65-173.

7. Alyasseri, Z.A.A., Khader, A.T., Al-Betar, M.A., Abasi, A.K., Makhadmeh, S.N., 2019. EEG Signals Denoising Using Optimal Wavelet Transform Hybridized with Efficient Metaheuristic Methods. IEEE Access 2019; 8, 10584-10605. doi:10.1109/ACCESS.2019. 2962658

8. Li, W., 2018 Wavelets for Electrocardiogram: Overview and Taxonomy. IEEE Access 2018; 7:25627-25649. doi:10.1109/ACCESS.2018. 2877793.

9. Zhang, J.H., Janschek, K., Bohme, J.F., Zeng, Y.J., 2004. Multi-resolution Dyadic Wavelet Denoising Approach for Extraction of Visual Evoked Potentials in the Brain. IEEE Proceedings-Vision, Image and Signal Processing 2004. 151(3), 180-186. doi: 10.1049/ip-vis:20040315.

10. Mintzer, F., 1982. On Half-band, Third-band, and Nth-band Fir Filters and Their Design. IEEE Transactions on Acoustics, Speech, and Signal Processing 1982. 30(5), 734-738. doi: 10.1109/TASSP.1982.1163950.

11. Boyd, S., Vandenberghe, L., 2004. Convex Optimization. USA: Cambridge University Press.

12. Donoho, DL., 1995. De-noising by Softthresholding. IEEE Transactions on Information Theory 1995. 41(3), 613-627. doi:13 10.1109/18.382009. 